НАУКОВИЙ ВІСНИК

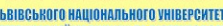

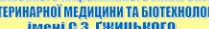
імені с.3. гжициького Scientific messenger of Livi National Uniersity
Veterinary Medicine and Biotechnolggies
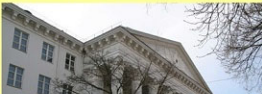
II: 19 it in F.

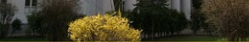

СЕРІЯ “ЕКОНОМІЧН НАУКИ"

Том 21 № 93

2019

Науковий вісник Дьвівського національного університету ветеринарної медицини та біотехнологій імені С.3. Гжицького. Серія: Економічні науки

\author{
Scientific Messenger of Lviv National University \\ of Veterinary Medicine and Biotechnologies. \\ Series: Economical Sciences
}

UDC 631.1.027

\title{
The problems of formation market veterinary services
}

\author{
S.I. Poperechnyi, L.V. Babych
}

Stepan Gzhytskyi national university of veterinary medicine and biotechnologies Lviv, Ukraine

Article info

Received 12.09.2019

Received in revised form 14.10.2019

Accepted 15.10.2019

Stepan Gzhytskyi National University of Veterinary Medicine and Biotechnologies Lviv, Pekarska Str., 50, Lviv, 79010, Ukraine.

Тел.: +38-093-706-12-07 E-mail:lesjbabutch@gmail.com
Poperechnyi, S.I., \& Babych, L.V. (2019). The problems of formation market veterinary services. Scientific Messenger of Lviv National University of Veterinary Medicine and Biotechnologies. Series: Economical Sciences, 21(92), 70-74. doi: 10.32718/nvlvet-e9314

The problems of formation of the market of veterinary services and application of the basic elements of marketing are considered. It is shown that transformation of main branches of agriculture on a market basis is combined with the initial stages of formation market of veterinary services. The factors that constrain these processes are analyzed. The main ones are difficult financial and economic situation of animals owners, the priority development of especially large entities that independently carry out all veterinary operations, the tendency of reducing the number of animals among potential customers of veterinary services. A significant influence of development of private enterprise in the field of veterinary services has a public veterinary service, which has largely monopolized the market for veterinary services. Having a wellestablished material base, knowledge and reputation of its specialists, in addition to measures related to controlling functions, the public service provides paid veterinary services. This complicates the efforts of private entities to develop private veterinary practices. The benefits of public service are compounded by the lack of risk of business activity. The provision of paid services is combined with public funding. The analysis of the factors of formation market demand for veterinary services, the main of which are the number and dynamics of animals owned by households, agricultural enterprises and other economic entities, the financial and economic situation of the owners of animals, their purchasing power, losses and losses of the animals owners due to the inadequate veterinary services, veterinary status of livestock breeding for infectious and invasive diseases, incidence of non-communicable diseases, opportunities for exp RTU products, the availability and accessibility of veterinary services in the market, the implementation of measures to stimulate demand for veterinary services and so on. A comparative analyze of behavior potential customers of veterinary services related to different market segments is made. The decision to order services to agricultural enterprises is made by the specialists of the enterprise, who are professionally trained, competent, as a rule, have agricultural education. This solution is characterized by a high degree of formalization that is not specific to individual animal owners. The expected trends in the development of the veterinary services market are analyzed. It is shown that the intensification of international integration processes and the elimination of non-tariff technical barriers to trade in agricultural and food products creates opportunities for increased exports of products. The latter is possible subject to proper veterinary care and the provision of a sanitary guarantee on this basis. This will encourage animal owners to order veterinary services, thus expanding the market capacity for these services.

Key words: veterinary service, market of veterinary services, marketing environment, competition, private veterinary practice, state veterinary service, factors of formation of demand for veterinary services, buying behavior of consumers of veterinary services.

\section{Проблеми становлення ринку ветеринарних послуг}

\author{
С.І. Поперечний, Л.В. Бабич
}

Львівський національний університет ветеринарної медицини та біотехнологій імені С.3. Гжиџького, м. Львів, Україна 
Розглядаються проблеми формування ринку ветеринарних послуг та застосування основних елементів маркетингу у даній сфері. Показано, щзо трансформація основних галузей сільського господарства на ринкових засадах поєднується з початковими етапами становлення ринку ветеринарних послуг. Аналізуються чинники, щуо стримують дані процеси. Основними є скрутне фінансово-економічне становище власників тварин, пріоритетний розвиток особливо великих за розмірами суб'єктів господарювання, які самостійно здійснюють усі ветеринарні операції, сталі тенденції скорочення поголів'я тварин у потенційних замовників ветеринарних послуг. Вагомий вплив на розвиток приватного підприємництва у сфері ветеринарного обслуговування має державна служба ветеринарної медицини, яка у значній мірі монополізувала ринок ветеринарних послуг. Володіючи сформованою матеріально-технічною базою, відомістю та репутацією ї̈ фахівців, крім заходів пов язаних із контролюючими функціями державна служба надає ветеринарні послуги на платній основі. Цим ускладнює намагання приватних структур щцоо розвитку приватної ветеринарної практики. Переваги державної служби посилюються відсутністю ризику підприємницької діяльності. Тут надання платних послуг поєднується із державним фінансуванням. Здійснено аналіз чинників формування ринкового попиту на ветеринарні послуги, основними з яких є чисельність та динамічні зміни показників поголів'я тварин, шуо знаходяться у власності домогосподарств, сільськогосподарських підприємств та інших суб'єктів господарювання, фінансово-економічне становище власників тварин, їх купівельна спроможність, втрати і збитки власників тварин через неналежне ветеринарне обслуговування, ветеринарний стан тваринництва за інфекційними та інвазійними захворюваннями, рівень захворюваності на незаразні хвороби, можливості експорту продукиї, наявність та доступність ветеринарних послуг на ринку, здійснення заходів стимулювання попиту на ветеринарні послуги тощо. Здійснено порівняльний аналіз поведінки потенційних замовників ветеринарних послуг, що відносяться до різних сегментів ринку. Рішення про замовлення послуг сільськогосподарськими підприємствами приймають фахівці підприємства, які є професійно підготовленими, компетентними, як правило, мають сільськогосподарську освіту. Таке рішення характеризується високим ступенем формалізацї, який не притаманний для індивідуальних власників тварин. Аналізуються очікувані тенденції розвитку ринку ветеринарних послуг. Показано, щз активізація міжнародних інтеграційних процесів та ліквідація нетарифних технічних бар'єрів у торгівлі продукиією сільського господарства та харчової промисловості створює можливості збільшення експорту продукиіі. Останнє можливе за умови належного ветеринарного обслуговування $і$ забезпечення на цій основі санітарної гарантії. Це стимулюватиме власників тварин замовляти ветеринарні послуги, шоо сприятиме розщиренню ємності ринку цих послуг.

Ключові слова: ветеринарна послуга, ринок ветеринарних послуг, маркетингове середовище, конкуренція, приватна ветеринарна практика, державна ветеринарна служба, чинники формування попиту на ветеринарні послуги, купівельна поведінка споживачів ветеринарних послуг.

\section{Вступ}

Ефективність функціонування невеликих за розміром суб'єктів господарювання можлива за умови сформованої сфери технічного, технологічного та ветеринарного обслуговування. Без цього майже не замітними будуть переваги реформування сільського господарства на засадах приватної власності і ринкових відносин. Свідченням цьому є переважний розвиток особливо великих підприємств, надзвичайно мляві процеси трансформування особистих селянських господарств у ринково орієнтовані фермерські господарства в умовах неналежно сформованої сфери надання послуг. У найневизначенішому становищі опинилась система ветеринарного обслуговування. Наукові дослідження даної системи, їх розгляд у публікаціях О.В. Кручиненко (Kruchynenko, 2017), А.В. Ничик (Nychyk, 2009), Ю.А. Уварина та Є.А. Фияксель (Uvarina \& Fijaksel', 2015) поєднуються 3 несформованістю загальноприйнятих підходів до організаційної побудови системи ветеринарного обслуговування, застосування доцільних елементів маркетингу.

Метою статті $є$ вивчення проблем формування сфери ветеринарного обслуговування та забезпечення iii ефективного функціонування на основі застосування основних елементів маркетингу. Для досягнення мети вирішувалися завдання: вивчити чинники, що стримують виникнення та розвиток недержавних суб'єктів, що можуть надавати ветеринарну послугу; дослідити маркетингове середовище у сфері ветеринарного обслуговування, здійснити аналіз поведінки споживачів ветеринарних послуг

\section{Матеріал і методи досліджень}

Дослідження здійснювалися на основі застосування загальноприйнятих наукових методів. Монографічний метод використовувався для вивчення стану ринку ветеринарних послуг. Економіко-статистичні методи використовувалися для аналізу рядів динаміки поголів'я тварин, чисельності потенційних замовників ветеринарних послуг.

\section{Результати та їх обговорення}

В Україні сформована нормативно-правова база функціонування системи ветеринарного обслуговування. Вона регламентується Законами України "Про ветеринарну медицину”, “Про підприємництво”, “Про ліцензування видів господарської діяльності” та затверджено Ліцензійні умови провадження господарської діяльності з ветеринарної практики. Однак належне законодавче і нормативне забезпечення поєднується 3 початковими етапами становлення ветеринарного обслуговування на ринкових засадах.

Формування та розвиток ринку ветеринарних послуг - це складний еволюційний процес, на який впливають історичні, культурні, природні, економічні, соціальні та політичні умови. Особливо важливим чинником становлення приватної ветеринарної практики є складне, турбулентне маркетингове середовище.

В умовах реструктуризації аграрного сектора економіки України у 90-х роках минулого століття пріоритетний розвиток отримали особисті селянські господарства. Тут утримується понад 60\% усіх видів тварин та виробляється понад $80 \%$ валової продукції тваринництва. Дані господарства характеризуються невеликими розмірами та незначними обсягами виро- 
бництва продукції. Проте з урахуванням їх кількості та чисельності в них поголів'я тварин, дані господарства $\epsilon$ найчисельнішими потенційними замовниками ветеринарних послуг.

Розукрупнено сільськогосподарські підприємства тваринницького профілю. Лише у третині з них утримується поголів'я тварин достатнє для найму штатного лікаря ветеринарної медицини. У решті, ветеринарні фахівці працюють на умовах неповної зайнятості. Рідше ветеринарне обслуговування у таких підприємствах здійснюється на умовах аутсорсінгу.

Скрутне фінансово-економічне становище власників тварин має безпосередній вплив на рівень проведення усіх необхідних ветеринарних заходів. Власники особистих селянських господарств та дрібних сільськогосподарських підприємств до ветеринарних фахівців звертаються лише у крайніх випадках. Це є однією із основних причин, що негативно впливає на розвиток приватної ветеринарної практики.

3 боку держави не здійснюється належна підтримка приватних структур ветеринарної медицини. Через високі ризики та невизначеність перспектив підприємницької діяльності в даній сфері не залучаються банківські кредити на придбання необхідного обладнання.

Вагомий вплив на розвиток приватного підприємництва у сфері ветеринарного обслуговування має державна служба ветеринарної медицини, яка у значній мірі монополізувала ринок ветеринарних послуг. Володіючи сформованою матеріально-технічною базою, відомістю та репутацією іiі фахівців, крім заходів пов'язаних із контролюючими функціями державна служба надає ветеринарні послуги на платній основі. Цим ускладнює намагання приватних структур щодо розвитку приватної ветеринарної практики. Перевага державної служби посилюється відсутністю ризику підприємницької діяльності. Тут надання платних послуг поєднується із державним фінансуванням.

Основним чинником розвитку приватної ветеринарної практики та створення життєздатних підприємницьких структур у даній сфері є стійкий попит на ветеринарні послуги.

До основних факторів формування ринкового попиту на ветеринарні послуги належать:

- чисельність та динаміка поголів'я тварин, що знаходяться у власності домогосподарств, сільськогосподарських підприємств та інших суб'єктів господарювання.

- фінансово-економічне становище власників тварин, їх купівельна спроможність;

- втрати і збитки власників тварин через неналежне ветеринарне обслуговування;

- ветеринарний стан тваринництва за інфекційними та інвазійними захворюваннями, рівень захворюваності на незаразні хвороби;

- можливості експорту продукції;

- наявність та доступність ветеринарних послуг на ринку;

- здійснення заходів стимулювання попиту на ветеринарні послуги тощо.
Ринок ветеринарних послуг диференційований. Потенційними замовниками цих послуг крім власників продуктивних $є$ власники домашніх тварин. Однак чисельність сімей, у яких утримуються домашні тварини постійно скорочується. За 2013-2018 роки, частка сімей у яких не утримуються домашні тварини зросла з 38 до 49 відсотків (рис. 1).

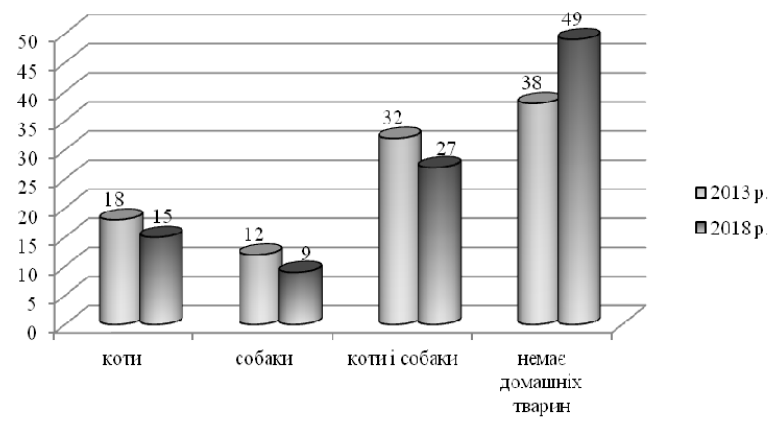

Рис. 1. Частка сімей в Україні, у яких утримуються домашні тварини, у відсотках до загальної кількості сімей (Koshki i sobaki v zhizni ukraincev, 2008)

Показники, що характеризують чисельність домашніх тварин суттєво диференційовані за місцем проживання власників. В сільській місцевості 78\% населення тримає дома котів та собак, у містах - лише $40 \%$.

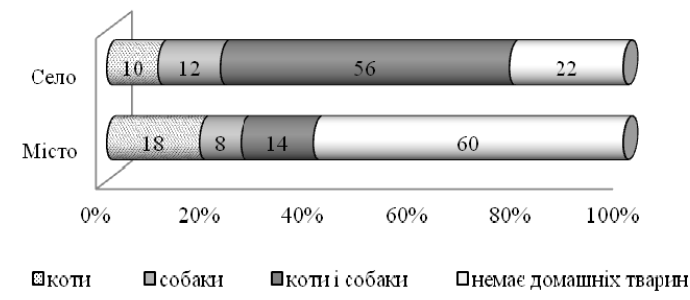

Рис. 2. Частка сімей залежно від місця проживання, у яких утримували домашніх тварин у 2018 році,

у відсотках до загальної кількості сімей

(Koshki i sobaki v zhizni ukraincev, 2008)

Потенціал даного сегменту споживачів ветеринарних послуг є значимим та привабливим для приватного підприємництва. Особливо активними на ринку ветеринарних послуг є споживачі, які проживають у містах.

Про привабливість даного сегмента свідчить і активна діяльність суб'єктів, що надають ветеринарні послуги. Наприклад, у Львові на даний час функціонує 39 суб'єктів, що обслуговують власників тварин. Лише чотири з них державної та комунальної форми власності. Решта функціонують на засадах приватного підприємництва. Це ветеринарні лікарні, клініки та кабінети. Між ними здійснюється як цінова, так i нецінова конкуренція. Вагомими чинниками нецінової конкуренції $є$ пакет пропонованих послуг, забезпеченість матеріально-технічними ресурсами та обладнанням, рівень професіоналізму персоналу тощо.

Купівельна поведінка власників продуктивних тварин суттєво відрізняється від такої поведінки власників домашніх тварин. Якщо визначальними у поведінці власників домашніх тварин є емоційні мотиви, 
то у поведінки власників продуктивних тварин вона формується на основі функціонально-вартісного аналізу. При цьому попит на ветеринарні послуги власників продуктивних тварин $є$ похідним від стану ринку продуктів тваринництва.

Загалом за 2009 до 2018 роки чисельність поголів'я сільськогосподарських тварин у Львівській області скоротилася з 495,9 до 454,6 тис. умовних голів (рис 3).

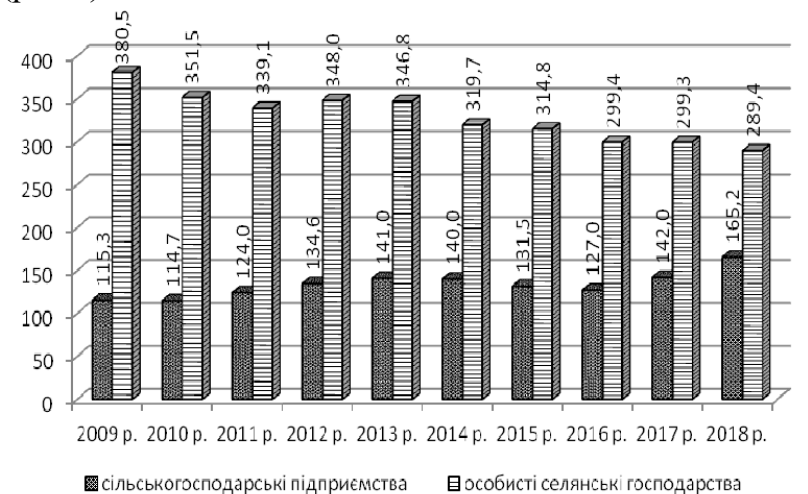

Рис. 3. Чисельність поголів'я основних видів сільськогосподарських тварин у Львівській області, тис.
Через стійку тенденцію зменшення поголів'я тварин в особистих селянських господарствах скорочується і попит на ветеринарні послуги на даному сегменті ринку.

Селянська сім'я, яка утримує одну корову, а площа земельних угідь не перевищує одного гектара, не може вважатись повноцінним суб'єктом ринкових відносин. Виробництво не має товарного характеру, а $\epsilon$ способом самовиживання. Тут не здійснюється належної роботи з профілактики захворювань тварин.

Власники особистих селянських господарств звертаються за послугами до ветеринарних фахівців лише за крайньої необхідності. В умовах скрутного економічного становища вони не здійснюють весь комплекс необхідних ветеринарних заходів. В результаті вироблена ними продукція не відповідає санітарним вимогам безпечності та якості.

Але 3 урахуванням обсягів продукції, яка тут виробляється, загальної чисельності поголів'я тварин, вони є важливими господарськими структурами, що мають значний вплив на формування ринку продовольства (рис. 4) і не можуть нехтуватись у процесі вивчення ринку ветеринарних послуг і попиту на них. ум. гол.

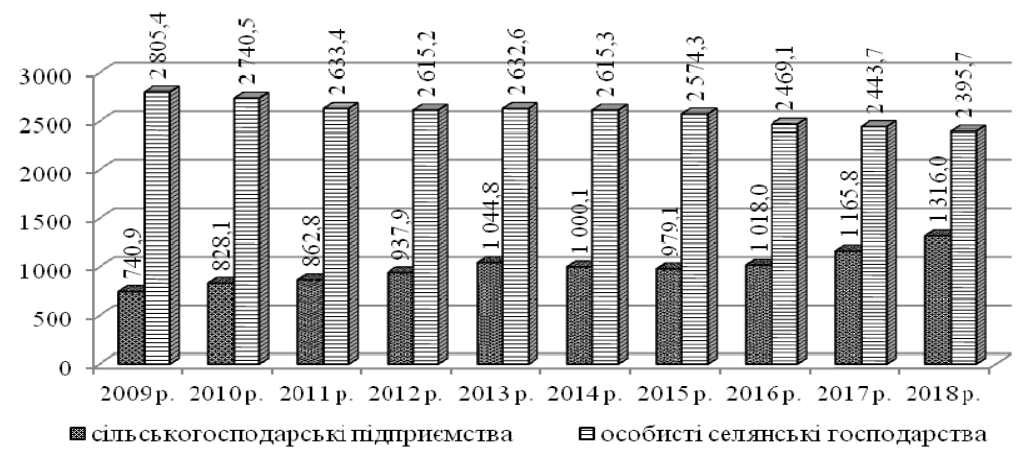

Рис. 4. Валова продукція тваринництва Львівської області (у постійних цінах 2010 року), млн грн

Актуальність та ефективність особистих селянських господарств як засобу виживання в перспективі знижуватиметься. Більшість з них покине галузь, а ті що залишаться перетворюватимуться у господарства ринкового типу зі стійким попитом на ветеринарні послуги. Зростання обсягів їх виробництва стимулюватиме дотримання усіх ветеринарних норм ведення тваринництва, а відповідно і ріст замовлень послуг ветеринарних фахівців.

Все ж трансформація особистих селянських господарств у ринково орієнтовані фермерські господарства товарного типу здійснюється дуже повільно. Не сприяють активізації таких перетворень зміни до Закону України "Про фермерське господарство”, якими передбачена можливість створення такого господарства без реєстрації його як юридичної особи, що є вагомим чинником звуження ємності ринку ветеринарних послуг.

Активізація міжнародних інтеграційних процесів та ліквідація нетарифних технічних бар'єрів у торгівлі продукцією сільського господарства та харчової промисловості створює можливості збільшення експорту продукції. Останнє можливе за умови належного ве- теринарного обслуговування і забезпечення на цій основі санітарної гарантії. Це стимулюватиме власників тварин замовляти ветеринарні послуги, що сприятиме розширенню ємності ринку цих послуг.

Потенційними замовниками послуг ветеринарних служб є невеликі сільськогосподарські підприємства. Даний сегмент ринку є привабливий для суб'єктів господарювання, що надають ветеринарні послуги. Поголів'я худоби, яке утримується в окремому підприємстві, суттєво перевищує поголів'я особистого селянського господарства, відповідно, обумовлює більший обсяг замовлення цих послуг.

Поведінка сільськогосподарських підприємствспоживачів ветеринарних послуг суттєво відрізняється від поведінки особистих селянських господарств. Рішення про замовлення послуг приймають фахівці підприємства, які є професійно підготовленими, компетентними, як правило, мають сільськогосподарську освіту. Таке рішення характеризується високим ступенем формалізації, який не притаманний для індивідуальних власників тварин.

Ветеринарне обслуговування тваринництва у Львівській області в основному здійснюється держав- 
ною ветеринарною службою, основним завданням якої $є$ забезпечення ветеринарного та епізоотичного благополуччя, здійснення державного ветеринарносанітарного контролю та нагляду. Поряд із проведенням контролюючих та профілактичних заходів щодо інфекційних захворювань, які фінансуються із державного бюджету, фахівці ветеринарної служби надають широкий спектр ветеринарних послуг за кошти власників тварин.

Наявна матеріально-технічна база державної ветеринарної служби не розрахована на надання повного комплексу ветеринарних послуг особистим селянським господарствам та дрібним сільськогосподарським підприємствам. Через дефіцит транспортних засобів та їх територіальну віддаленість від господарств, де утримуються тварини, існують гострі проблеми із наданням невідкладних послуг. Подолати їх можливо на основі пропагування і активізації процесу формування недержавних структур ветеринарної медицини.

\section{Висновки}

Попит на ветеринарні послуги є похідним від попиту на продовольчі товари тваринницького походження. Втрата конкурентних позицій невеликими виробниками на ринку продукції тваринництва, їх скрутний фінансовий стан , є однією із основних причин, що стримує становлення та розвиток недержавних суб'єктів, що можуть надавати ветеринарні послуги. Проблема посилюється неналежним дослідженням ринку. Його сегментація дозволяє виявити привабливі сегменти, на яких служби, що надають ветеринарні послуги можуть забезпечити ефективне функціонування.

\section{References}

Koshki i sobaki v zhizni ukraincev (2008). Research and Branding Group. http://rb.com.ua/blog/koshki-isobaki-v-zhizni-ukraincev (in Russian).

Kruchynenko, O.V. (2017). Kontseptualni osnovy marketynhovoho planuvannia pidpryiemstva $\mathrm{v}$ haluzi vetery-narnoi medytsyny. Visnyk Kharkivskoho natsionalnoho ahrarnoho universytetu imeni V.V. Dokuchaieva. Ser. Ekono-michni nauky, 2, 192-202. http://nbuv.gov.ua/UJRN/Vkhnau_ekon_2017_2_22 (in Ukrainian).

Kruchynenko, O.V. (2017). Teoretychni aspekty formuvannia rynku veterynarnykh posluh u tvarynnytstvi. Visnyk Dnipropetrovskoho derzhavnoho ahrarnoekonomichnoho universytetu, 4(46), 98-102. http://nbuv.gov.ua/UJRN/vddau_2017_4_19 (in Ukrainian).

Nychyk, A.V. (2009). Ekonomichna efektyvnist derzhavnoho veterynarnoho obsluhovuvannia V Ukraini na pryk-ladi Sumskoi oblasti. Visnyk SNAU. Ser. Ekonomika ta menedzhment, 8(37), 72-78 (in Ukrainian).

Nychyk, A.V. (2009). Teoretyko-metodolohichni zasady formuvannia rynku veterynarnoho obsluhovuvannia. Ah-roinkom, 1-4, 20-24 (in Ukrainian).

Uvarina, Ju.A., \& Fijaksel', E.A. (2015). Sozdanie ontologii biznes-modelej dlja rynka veterinarnyh uslug kak innovacionnyj metod upravlenija kompanijami. Innovacii, 10(204), 95-101. https://cyberleninka.ru/ article/n/sozdanie-ontologii-biznes-modeley-dlyarynka-veterinarnyh-uslug-kak-innovatsionnyy-metodupravleniya-kompaniyami (in Russian). 